\title{
Josiah Osgood, Turia: a Roman Woman's Civil War, Oxford University Press, Oxford 2014, pp. 215.
}

The latest book by Josiah Osgood on the famous and only partially preserved funerary stela of a woman who became to be referred to by historians as "Turia" belongs to a series of books dedicated to various historical female protagonists and is titled Women in Antiquity. The series is edited by the world-renowned scholars on the subject of women in antiquity, Ronnie Ancona and Sarah B. Pomeroy, which had already published works on such famous personalities as Cleopatra, Arsinoë, Berenice II or Faustina I and her daughter Faustina the Younger ${ }^{1}$. The fact they the editors have chosen to devote the next volume of the series to an unknown woman living in the $1^{\text {st }}$ century $B C$, whose identity is still a real mystery to historians, suggests a genuine interest in developing further the so-far rather marginal studies on ordinary women in Rome. The second quite surprising fact was the choice of author for the volume on laudatio Turiae. Josiah Osgood, the Georgetown University professor in classics, has been so far known mainly for his brilliant publications on the political turbulences in the male-dominated arena of conflicts during the periods of the Late Roman Republic and Julio-Claudian dynasty ${ }^{2}$. Without diminishing Osgood's academic and writing skills, evident in his superb publications mentioned above, his authorship of the book on a Roman woman is certainly quite unexpected, particularly since the historians who have been formerly publishing books for the Women in Antiquity series are, unlike Osgood, specialists in the area of ancient women's lives. The book confirms, however, Osgood's prolificacy and flexibility in confronting various historical themes.

In a sense, the book returns to a familiar and already vastly researched problem of the funerary relief, made by a husband after the death of his beloved wife. Since there are only a few parts of the entire stela preserved and available for study, and no new elements have recently come to light, revisiting the well-known and analysed artefact could have appeared as futile. The author, however, as an "outsider" in the area of studies on ancient women, approaches the relief from a new and more flexible perspective than is usually done in typical historical biographies. The inscriptions from the funerary stela, even though fragmentary and limited in their information, are used only as a point of departure for speculating a story of "Turia's" activities at certain points in time. Because the book is arranged chronologically (from „Turia's" earliest important event - taking revenge for her parents' death - to her own death, a reminder of which is the hus-

${ }^{1}$ D. W. Roller, Cleopatra: A Biography, Oxford 2011; E. Donnelly Carney, Arsinoë of Egypt and Macedon: a Royal Life, Oxford 2013; D. L. Clayman, Berenice II and the Golden Age of Ptolemaic Egypt, Oxford 2013; B. M. Levick, Faustina I and II: Imperial Women of the Golden Age, Oxford 2014.

2 J. Osgood, Caesar's Legacy: Civil War and the Emergence of the Roman Empire, Cambridge 2006 and Claudius Caesar: Image and Power in the Early Roman Empire, Cambridge 2010. As for the articles to name just a few: Suetonius and the Succession to Augustus, in: The Julio-Claudian Succession: Reality and Perception of the Augustan Model, ed. A. Gibson, Brill 2012; Caesar and the Pirates; or How to Make (and Break) an Ancient Life, "Greece \& Rome” 2010, pp. 319-336; Caesar and Nicomedes, "The Classical Quarterly" 2008, 58, pp. 687-691; The Vox and Verba of an Emperor: Seneca, Claudius, and le prince ideal, „The Classical Journal” 2007, 102, pp. 329-354. 
band's laudatory relief), the incidents from the wife's life, known from the surviving inscriptions, are interwoven to and finally merged with the larger picture of the political havoc starting in $49 \mathrm{BC}$ with the war between Julius Caesar and Gn. Pompey. Her life is placed against the backdrop of the most critical and highly dangerous for her family conflicts, spanning at least from late 50s and continuing until the 20s. She does not stand in the isolation from these events though. Osgood defines her life through the comparison to other, more famous, women of that time, drawing a conclusion that „Turia”, like so many other wives, daughters and mothers living in the second half of the $1^{\text {st }}$ century $\mathrm{BC}$, was determined to survive the calamities befalling her.

Throughout the book „Turia” herself is referred to only as "the wife" since the author prefers to avoid the repetition of standardly accepted, yet unproven, version of that woman's name. This new "name” for the protagonist presents an opportunity to follow an actual information from the relief (on the preserved parts of which the name of the wife is indeed not disclosed), but also to set this woman's life as a more generalised and all-encompassing example of what other wives of that historical period had to suffer through. The wife is therefore representing thousands of potential victims of injustice, proscriptions and civil discords, but at the same time she is distinguished from other women by her higher social status and her husband's evident involvement in the politics. On the other hand, as a representative of females who suffered the violent abuses and turmoils of wars, she is set apart from other women thanks to her unrelenting devotion to her husband and her inner stamina. Since only 7 pieces of the laudatio Turiae remain for historians to analyse, Osgood does not write a typical biography of this woman. The author by default builds up the image of the wife which for the most of the time is greatly conjectural. He warns the readers about some of the elements in "Turia's" story being purely speculative, but he nevertheless slowly establishes some potentially possible events in the wife's life as facts. The question is whether the author does not take this hypothetical technique of forming some of the facts in this woman's life a little too far. It is only due to comparisons to women from the $1^{\text {st }}$ century, wellknown, famous in their spheres, referred to by the ancient sources, that the wife's life can gain a more thorough historical and social context. The comparative approach allows Osgood to juxtapose the preserved information on the activities of "Turia" with those of Servilia or Octavia, hence providing a scope of highly likely events in „Turia's" turbulent life. Since her husband was a senator, siding with the "wrong" group in politics, her actions, similarly to those of i.e. Porcia or Hortensia and determined by the dramatic circumstances, must have been practically the same to all the women opposing the acting regime. The image of the wife is consequently constructed on the evidence available from the written sources on women of the late republican period. In itself, the methodology of the study offers nothing new.

Dividing the book into eight chapters evokes eight stages in the history of Rome and the life of the wife. Each corresponds also to the lives of the most prominent women of Rome at a specific point in time. "Turia's" activities are weaved into the colourful and usually dramatic lives of Roman matronae and their examples are set as a context background for proving the wife's courage and exceptional qualities. The first chapter (Father's Death) gives general information on the concepts of paterfamilias and tutela legitima, explaining a role of "Turia" within the framework of her family situation after the murder of her parents. By drawing examples from Pro Roscio Amerino and referring to lex Voconia, Osgood draws a picture of various circum- 
stances which could have been responsible for positioning „,Turia” in a dreadful condition of an orphan deprived of both money and means of fighting for the right to regain her parents' fortune and avenge their death. This chapter is probably the vaguest in terms of retracing the exact means by which the protagonist managed to restore her own position and bring her parents' murderers to justice. There are also no immediate comparisons to any eminent women of that period. The author has a very limited section of the inscription left on the early activities of "Turia” to work with and keeps his assumptions within the sphere of guesses, emphasising rather the steadfastness of the wife, a prediction of her further determination in life, and an apparent success in protecting her interests. He refers nevertheless to the notion of justice in the Roman Republic, emphasising that taking vengeance for the death of family members was deeply rooted in the mentality of not only men, but also women. Osgood stresses that the Roman society and the judicial system of Rome gave specific chances to "Turia" for defending her rights, thus breaking with the generally accepted view that women must have been mere victims in the times of political chaos. He points at the wife's sister as the second woman who, by individual efforts, managed to regain what had been taken away from her. The sisters managed to disclose the truth about the seized fortune of their parents and win the court case against the alleged kinsfolk of their father who had illegally expropriated the family estates. The story, even though the details are not known, gives a fascinating portrayal of the everyday intrigues and dangers a woman in Rome could have faced had she not taken a husband or at least a guardian to advocate her cases during the civil strife so typical for the last decades of the $1^{\text {st }}$ century BC. The chapter proves that even a single and orphaned young woman could have been supported by the Roman justice system and reclaim their honour and wealth.

The second chapter moves to the most important event in "Turia's" life - her getting married. The engagement of the couple does not seem to have a very happy beginning though for $\mathrm{Gn}$. Pompeius and the remaining senators in Rome, together with any supporters willing to join them, flee from Italy and Caesar. The future husband, who belonged to the Pompeian party, was in need of his fiancée's support in providing money and in protecting all of his financial and family matters even though the woman was still not officially his wife. In the end, the wife-to-be emerges victorious from all the turbulent events: she protects her own life, her future husband's family and his estates/fortune from the marauders of Milo. Throughout the two years of war, the wife pursues, however, even more ambitious plan: interceding for her future husband in case the war was lost by the Pompeiani. The disastrous campaign of Pharsalus and Caesar's attitude towards the defeated supporters of his rival would have defined the entire future life of „Turia". In order to have her fiancé's pardon granted she goes on to openly plead for his life. Despite Caesar's general amnesty to the men fighting against him at Pharsalus, it must have been crucial to know some of the well-respected matronae of the aristocratic gens to intercede for the men returning home after the war. To guarantee her fiancé's safe passage back home, the wife must have been in touch with other women from the highest social strata, like Julia, the mother of Marcus Antonius. The author describes the world of possibly quite intricate political dependencies and connections between the women of rich Roman houses, who quite often interfered with standard war-like conducts of their husbands, fathers and sons, in order to secure the fortunes and lives of other women's husbands, fathers and sons. Osgood evokes for example Terentia, the wife of Cicero, as 
one of the mediators in the affairs between her husband and M. Antonius, as well as, in later period, between herself and Antonius' mistress, Volumnia, on behalf of Cicero. The world of women emerging from the two years of civil war shows that they were both passive observers of the injustice done to their everyday lives, but also energetic participants in saving their menfolk. Osgood correctly reiterates that their activity was expected by and extremely useful to their husbands. They were the extension of their partners' political and social world. Similarly, „Turia" proved herself to be selfsufficient and unfailing fiancée during the times of great danger, and she managed to independently handle her future husband's financial and political problems, first through selling her jewels to support her fiancé's war campaigning and then by mediating his honourable return from war. Marriage was a result of her reliability.

The third chapter further introduces the dramatic events after the death of Caesar, the crisis in the Senate during M. Antonius' siege at Mutina and, finally, the fall of Perugia resulting in the Romans fleeing to Sextus Pompeius in Sicily. The entire chapter revolves not so much around the political affairs, but around behind-thescenes activities of women such as Servilia, Hortensia and Fulvia, all boldly engaged in supporting their men in accordance with the circumstances. Servilia is evoked as the outspoken head of the family in the period after the Ides of March, directing the political path of her son Brutus. Hortensia emerges as a female orator, publicly defending the rights of women charged with taxes. Finally, Fulvia, the most colourful character of all, acts as a main party in the conflict with the young Caesar and impudently leads soldiers to war against him. Osgood builds up the narrative on the wife's participation in the critical times by placing her alongside these women. The admiration of the husband, as well as the author of the book, is best expressed in the wife's courageous saving of her spouse during the proscriptions. The theme of "Turia's" daring idea of hiding her husband in the attic of a house is preceded by her appeal in front of M. Lepidus when she was brutally driven away from the triumvir's presence. Considering the severity of political conditions women had to face, these two events marked the wife's outstanding sacrifice for her husband. Osgood naturally praises the heroine, deservedly applauding her devotion to the family life. But by comparing „Turia” to other women, particularly to Julia, the mother of the Antonii and Fulvia, the wife of the triumvir, she also starts to emerge as more ordinary, a woman like many others who were ready to give up their lives for their loved ones. The poignant moment of saving her husband from violent proscriptions fits in nicely in the middle of the book, providing a pinnacle of the wife's inner strength. In her extraordinary courage Osgood sees, however, the element of a very humane behaviour, thus making her not so much a typical heroine worthy of admiration, but a representative of so many various women struggling at that time to survive.

From the fourth chapter onwards the book slightly changes its nature as focuses primarily on the more domestic rather than political character of women's participation in various events. Not by chance, the more intimate matters in the wife's life coincide with a much quieter and peaceful time in Roman politics. The wars with Sextus Pompeius, even though still affecting the internal situation of the State, do not immediately threaten "Turia" and her husband. The couple is said to have planned their family life, but the wife failed at giving her husband a child. The relief informs that she offered her husband a simple solution of divorcing him and allowing him to marry another woman for the purpose of having offspring, at the same time placing herself at the ex-husband's financial control in a role of a loyal sister or mother-in-law. As 
much as Osgood offers a detailed explanation of the importance of a Roman woman's childbearing, within the social and political context referring mainly to legal aspects of sharing the inheritance, wife's dowry, etc., he does not put enough emphasis on the emotional and psychological aspects of the wife's plan. The husband, as the relief confirms, was clearly distraught and outraged at his wife's proposal. The author, through the analysis of females' standardised roles as mother and wives, brings to attention only the aspect of women's obligations within marriage. But the husband's emotional outburst is attributed not so much to the wife's failed obligations, but most of all to his devotion and love for the wife. These sentiments, most assuredly present in the couple's relationship, were behind the man's reaction. He set his wife apart mainly for her honourable moral values and undying loyalty and not for her ability to give birth to his children. After all, the problem of her childbearing is pushed at a margin once her former achievements are recalled. The relief confirms that the "stereotypical" Roman husband confining his wife to the domestic circle of motherhood was by no means a standard picture of the Roman males. Osgood's examination of other women whose life was determined by childbearing, like Fulvia's or Octavia's, places the motherhood in the centre of the ancient Roman female existence. Unquestionably, having offspring had often political ramifications and was dictated by the social convention. But the wife, due to her husband's touching words engraved on the relief, managed to avoid having a childlessness stigma attached to her. Overall, the situation the wife found herself in may not have been uncommon in other marriages of the late $1^{\text {st }}$ century $\mathrm{BC}$ and early $1^{\text {st }}$ century AD. The Augustan marriage legislation was officially introduced as an answer to all the unmarried and childless women and men as well as the infidel spouses whose role, according to Augus- tus, was to renew the concept of the Roman domus, procreate and heal the very strained morale of Roman women. Even though the wife's circumstances were different than those pointed out by Augustus' laws, the policy to reinstate the Roman family tradition must have been particularly harsh on women and examples of their discontentment were widely known. Unfortunately, Osgood gives little credit to these matters. The book nevertheless presents the institution of the Roman marriage with accuracy and care, explaining the most fundamental personal dependencies due to which „Turia" found her infertility so excruciatingly unbearable.

The part on the wife's death is, due to the subject matter, the most poignant but also the least detailed chapter of the book. It addresses the mournful words of the husband, lost without his beloved wife. His confusion on how to manage life without "Turia" is an example which writes in to the genre of the laudatio, but is, first and foremost, a very individual expression of grieving. Osgood attempts to define these limits of grief in accordance with the accepted by the Romans norms of mourning for the deceased. His examples of Caesar and Augustus, who allegedly suppressed their anguish after the loss of the beloved daughter and grandchildren respectively, stand, however, in sharp contrast to the emotional breakdown of Octavia after her son's death. The emphasis of the author is placed on a more intimate and deeply individual experiencing of death, divorcing it from a strictly sociological context of organising the funerary rites. Evoking Cicero's desperation after the premature death of his only daughter Tullia, the chapter emphasises that even for the philosophically inclined Romans the event of the beloved person's death was transcending the framework of a stoic, or for that matter a psychological, comprehension of the loss. The death of the wife is explained within the emotionally-driven setting of the life of 
the husband who will have to manage his wife's funeral, having no one to support him in his darkest hours. The funerary rites are described in the next chapter, explaining the organisation of the entire funerary procession and the roles of the mourners. The author refers to the iconography of some of the marble reliefs on sarcophagi and goes back to the poetry of Catullus and Propertius to express the Roman understanding of funerary ceremonial. Laudatio is in itself presented as an integral element of every mourning process- together with the necessary enumeration of the deceased virtues and lamentation after their death. The glorification of the dead person's moral conduct expressed to the world of the living, as a fundamental part of the Roman tradition, sets the wife's relief as quite standard and expected form of farewell. Osgood, through his addition of ancient poetry's analysis, manages however to mark this moment as particularly poignant and melancholic.

The last two chapters of the book are less concerned with the historical and social background of the period in which "Turia" and her husband lived, but follow the actual identities of the couple. Through his studies of Dio, Appian, Nepos and Mommsen, the author argues that it is most likely that the couple in question is not Lucretius Vespillo and his wife Turia. He does not give the identities of the couple though apart from stating that they were people of a high social class and, through the husband - a senator, were directly involved in the politics. It is a little disappointing that no new evidence came to light to confirm the lives of "Turia" and "Lucretius", but Osgood is right in refraining from giving any hasty conclusions. Instead he draws a broad picture of the period under transition not only in politics, but also in the lives of Roman women. He forwards his arguments to the problem of the Augustan household and women like Octavia and Livia, whose recognition and admiration gained throughout their lives elevated also the status of so many other women of the senatorial clans. Using the example of his sister and wife, Augustus redefined the concept of femininity, but only through placing on his sister and wife specific titles which demanded from others a particular form of revering these women. Interestingly enough, Osgood hardly ever mentions Julia, the daughter of Augustus, who is clearly not fitting into the accepted trend of "good women". Unconsciously, the author repeats the standard pattern of dividing Roman women into good and bad, out of whom „Turia" has to be classified as belonging to the first group ${ }^{3}$. Augustus' daughter is generally pushed aside as Osgood automatically places her amongst „bad" women and thus not worthy of any comparison to the book's protagonist. On a more positive aspect of the book, the author, admitting that any perspectives for women on freedom were quickly curtailed by a prudish, at least on the outside, Augustus, takes the problem of the emperor's marriage legislations one step further and defines what has been long left unsaid in the academic world - the couples in ancient Rome did have relationships based on love and genuine affection. This very „unscholar" thesis agrees, however, with the picture drawn by the husband. Regardless of the changes on marital laws emerging throughout Augustus' reign, there must have existed strong bonds between many married couples based not so much on calculated benefits on entering the marriage, but on mutual respect, passion and undeniable love. For Osgood this most basic connection between a man and a woman

${ }^{3}$ He does not really try to examine to possibility of the wife acting not necessarily in accordance with the Roman social standards. Perhaps this derives from the lack of historical evidence on "Turia", but each laudatio should be, in my opinion, scrutinised also as a text generally devoid of objectivity. 
could easily determine the lives of married couples in Rome, thus giving them a context which is much closer to the $21^{\text {st }}$ century readers of his book.

Even if the wife is an exemplary matrona fulfilling her pudicitia and loyalty towards her husband, Osgood managed to save the heroine from the standardised and most often stereotypical image of ancient Roman woman. She appears both brave and strong, but through the political circumstances of the times she lived in, she is automatically taken out of the framework of typically meek and frail female running the household. The wife's daring activities conducted on her own behalf and dictated by her husband's political affiliations are in agreement with the deeply moving image emerging from the laudatio. The strength of the book is its emotional honesty where Osgood does not try to convince us that the wife was extraordinary. The monument in a form of the relief is in itself the best evidence for her amazing personality. It is possibly one of a very few books written by the actively working academic who takes into consideration and emphasises the role of the most human feelings - of love, fear, grief and gratitude, empathising with the protagonist, but without any extensive form of applauding her deeds. It can be said that the book is possibly closer to a short introduction to the lives of Rome women during the times of the Republic's decline than a strictly scientific and broad analysis of the preserved funerary relief. It nevertheless offers insight into the Romans' everyday duties, activities and problems. The women presented and their politicosociological conventions remain overall at the mercy of men, but a glimpse of female strength and individuality allows for perceiving "Turia" and other matronae of the Roman state as skilful warriors, intelligent allies and lucky survivors.

The two appendixes offered by Osgood are additional incentives to reading this beautifully written work, particularly the author's own superb translation of the laudatio alongside the Latin version of the inscription. I believe any scholar will find in this book several arguments worth considering while any ancient Roman history amateur will be able to study this book's details with real pleasure.

Anna B. Miaczewska (Lublin) miaczewska@interia.pl

BIBLIOGRAFIA:

Roller D. W., Cleopatra: A Biography, Oxford 2011. Donnelly Carney E., Arsinoë of Egypt and Macedon: a Royal Life, Oxford 2013.

Clayman D. L., Berenice II and the Golden Age of Ptolemaic Egypt, Oxford 2013.

Levick B. M., Faustina I and II: Imperial Women of the Golden Age, Oxford 2014.

Osgood J., Caesar's Legacy: Civil War and the Emergence of the Roman Empire, Cambridge 2006.

Osgood J., Claudius Caesar: Image and Power in the Early Roman Empire, Cambridge 2010. 